Monika Kubiaczyk

(Poznań)

https://orcid.org/0000-0002-6271-7678

\title{
SZLACHETNI SZALEŃCY CZY ZWYKLI ZLODZIEJE? WYBRANE ASPEKTY PROBLEMU KRADZIEŻY KSIĄŻEK NA PRZESTRZENI WIEKÓW*
}

\begin{abstract}
This paper analyzes the phenomenon of book theft, sometimes referred to somewhat frivolously as bibliokleptomania. The essential goal is to outline the motives behind such practices and, based on that, develop a typology of book thieves.
\end{abstract}

\section{Key words}

libraries, manuscripts, books, thieves, bibliokleptomania, anathema

\section{WPROWADZENIE}

Jedyną rzeczą gorszą od złodzieja książek jest zarazek kiły.

Pliniusz Młodszy pisał, że „w bibliotekach przemawiają nieśmiertelne dusze zmarłych"1 (in bibliothecis loquuntur defunctorum immortales animae), zatem każda kradzież książek może być postrzegana w kategoriach naruszenia sfery sacrum. Rzecz jednak nie jest tak oczywista, jak się wydaje. Zasadniczym celem mojej pracy

* Praca powstała pod kierunkiem prof. UAM dr hab. Katarzyny Krzak-Weiss w ramach Podyplomowych Studiów Edytorstwa na Wydziale Filologii Polskiej i Klasycznej UAM w Poznaniu.

${ }^{1}$ Słowa te odczytywane dzisiaj brzmią nieco patetycznie. Starożytni jednak inaczej niż my postrzegali kwestie nieśmiertelności i duszy. Zob. Rohde 2007. 
jest ukazanie złożoności i wieloaspektowości problemu kradzieży książek, często nazywanej bibliokleptomanią, choć pragnę polemizować z tym nieadekwatnym terminem. W centrum mojego zainteresowania znajdują się złodzieje książek. Zależy mi na przedstawieniu ich wybranych sylwetek, przyjrzeniu się motywom mniej lub bardziej szlachetnym, które nimi kierowały. Na tej podstawie podejmuję próbę stworzenia własnej typologii złodziei książek. W tytule pracy nawiązuję do jednej z kluczowych książek dotyczących tego problemu autorstwa Nicholasa A. Basbanesa².

Zdając sobie sprawę z ogromu przedsięwzięcia i własnych ograniczonych możliwości, chciałabym podkreślić, że niniejsza praca jest wyłącznie szkicem lub wstępem do badań. Interesuje mnie kilka podstawowych kwestii. Po pierwsze, metody walki ze złodziejami i sposoby, które miały chronić książki przed kradzieżą. Szczególne miejsce zajmują tu średniowieczne przekleństwa na tych, którzy chcieliby ukraść książkę. Mają one olbrzymie znaczenie, jeśli spojrzymy na nie przez pryzmat epoki, w której powstały. Ich obrazowość, czasami dosadność i okrucieństwo, nawet dziś budzą zdumienie. Po drugie, analizuję kradzież książek jako problem etyczny. Utarło się bowiem przeświadczenie, że „kradzież książek to nie kradzież”. Chcę się przyjrzeć samemu aktowi kradzieży, jego ocenie moralnej i konsekwencjom prawnym. Po trzecie, interesują mnie złodzieje książek, chcę pokazać, jak często to obrońcy bibliotek i miłośnicy książek dopuszczali się kradzieży, ale spróbuję też odpowiedzieć na pytanie, czy to oznacza, że w tym momencie przechodzili na ciemną stronę. Pytanie istotne, bowiem myślenie binarne zawodzi, kiedy złodziejami stają się strażnicy książek, bibliotekarze i bibliofile. Okazuje się, że ich motywacje nierzadko są bardzo szlachetne. Kradzież była czasami jedynym sposobem ocalenia bezcennych zbiorów przed zagładą lub zapomnieniem. Na swoisty paradoks związany z niszczeniem zbiorów zwraca uwagę Fernando Báez. W swojej pasjonującej książce, ukazującej kulturową grabież Ameryki Łacińskiej przez Hiszpanów, ironicznie zauważa, że czasami Europejczycy, którzy niszczyli dzieła i dorobek tamtejszych kultur w okresie konkwisty i później, przechodzili do historii jako bibliofile i fundatorzy bibliotek czy też osoby, których imionami nazywano nobliwe instytucje naukowe (vide przykłady Juana de Zumárragi i Diego de Landy) ${ }^{3}$. Myślę, że można uznać to za okrutny chichot historii z europocentryzmem w tle.

Zjawisko kradzieży książek ma dość bogatą literaturę. Najnowszą i najpełniejszą publikacją jest „Roba este libro. Introducción a la bibliocleptomanía”, autorstwa Miguela Albero Suaréza ${ }^{4}$, byłego ambasadora Hiszpanii w Hondurasie. Poza analizą fenomenu „bibliokleptomanii”, zawiera ona opis tzw. peryferiów biblioklepto-

\footnotetext{
2 Basbanes 1995.

3 Báez 2009, s. 46.

4 Albero Suárez 2017.
} 
manii, to jest kwestii nieoddawania książek do bibliotek, ich niszczenia, plagiatowania czy piractwa. Jak przystało na publikację o złodziejach książek, dzieło ma skradziony tytuł, do czego zresztą autor się przyznaje z rozbrajającą szczerością. Albero Suárez prezentuje własną klasyfikację złodziei książek (ladrones de libros). Wyróżnia: złodzieja-czytelnika i złodzieja-pisarza, złodzieja-bibliofila, złodzieja-wydawcę, złodzieja-kleptomana i złodzieja-bibliotekarza5. Autor oparł się na wielu ustaleniach swoich poprzedników, również zajmujących się problemem kradzieży książek. Jednym z nich jest Nicholas Andrew Basbanes, autor wspomnianej już „A Gentle Madness. Bibliophiles, Bibliomanes, and the Eternal Passion for Books", niezwykle erudycyjnej książki. Analizuje w niej między innymi przypadek Stephena Carrie Blumberga, najbardziej znanego amerykańskiego złodzieja książek (ukradł ich ponad 23 tysiące!). Na marginesie warto dodać, że Basbanes jest jednym z najlepszych specjalistów zajmujących się badaniem kultury i dziejów książki, autorem kilku monografii i wielu artykułów czy esejów dotyczących tej tematyki. Z wcześniejszych prac warto wymienić broszurkę „Notes on bibliokleptomania", której autorem jest Lawrence $S$. Thompson ${ }^{6}$. Mimo niewielkiej objętości wnosi ona bardzo wiele do badań nad problemem kradzieży książek. Na gruncie polskim problem kradzieży książek nie doczekał się monografii, choć sporo informacji odnajdujemy u Szyndlera ${ }^{7}$.

\section{W POSZUKIWANIU WŁAŚCIWEGO OKREŚLENIA}

Proceder uprawiany przez złodziei książek nie ma w pełni adekwatnej nazwy, używa się często zamiennie, choć błędnie, terminów: bibliokleptomania, bibliomania, bibliofilia czy biblioholizm. Słowo „bibliokleptomania” składa się $\mathrm{z}$ trzech członów pochodzących z języka greckiego, $\beta \mathrm{\iota} \beta \lambda$ íov, biblion - książka, $\kappa \lambda \varepsilon \dot{\pi} \tau \varepsilon ı$, kleptein -kraść, gr. $\mu \alpha v i \alpha$, mania - szaleństwo, obłęd. Zatem bibliokleptomania byłaby kradzieżą książek powodowaną obłędem. Czy jednak odnosi się to do wszystkich złodziei książek? Jak słusznie zauważa Miguel Albero Suárez, „wszyscy bibliokleptomani ${ }^{8}$ są złodziejami książek, ale nie wszyscy złodzieje książek są bibliokleptomanami"9 (tłum. M.K.). Złodzieje książek mieli różne powody, aby kraść, od najbardziej przyziemnych aż po wzniosłe. Używane i rozpowszechnione przez Nicholasa Basbanesa słowo „bibliomania”, od gr.

\footnotetext{
5 Albero Suárez 2017, s. 9-10.

6 Thompson 1944.

7 Szyndler 1982.

${ }^{8}$ Co ciekawe, Wielki Słownik Języka Polskiego nie notuje słów: bibliokleptomania czy bibliokleptoman. Odmieniam je analogicznie jak „piromania” i „piroman” czy „melomania” i „meloman”.

9 Albero Suárez 2017, s. 21.
} 
$\beta \iota \beta \lambda i o v$ i $\mu \alpha v i \alpha$ oznacza obsesję, obłęd na punkcie książek ${ }^{10}$. W gronie bibliomanów znajdą się więc wszyscy, którzy kochali i kochają książki właśnie miłością obsesyjną, nakazującą im gromadzić ich olbrzymie ilości, ale także zdobywać je za wszelką cenę i wszelkimi sposobami. Kradzież jest tylko jedną z metod, może nie najbardziej chwalebną, czasami ostatecznościąa ${ }^{11}$. Bibliofilia czy bibliofilstwo, pochodzą od greckich $\beta \iota \beta \lambda i ́ o v$ i $\varphi \iota \lambda \varepsilon ́ \omega$, phileo (kochać). Jak twierdzi Bartłomiej Szyndler, „bibliofile to ludzie kochający książki i gromadzący je z dużym znawstwem" ${ }^{12}$. Przy czym interesuję się nie tylko szatą zewnętrzną książek, ale także ich treścią. Biblioholizm zaś powstał z połączenia gr. $\beta ı \beta \lambda$ íov i öloc, holos - cały i oznacza silne uzależnienie od obcowania z książkami. W moim przekonaniu bibliomania, bibliofilia i biblioholizm są terminami wyjątkowo nieostrymi, mają ogromny zakres znaczeniowy, a ustalenie granic pomiędzy nimi jest niemożliwe. Natomiast „bibliokleptomania”, oznaczająca wyłącznie chorobową konieczność kradzieży książek, jest terminem zbyt wąskim.

Najbardziej adekwatnym określeniem, w moim odczuciu, jest bookthief (ang.), robo de libros (hiszp.), czy po polsku kradzież ksiażek. Podobnie jest ze „złodziejem książek", którego najlepiej oddaje angielski termin biblioklept. Na gruncie języka hiszpańskiego Albero Suárez proponuje użycie określeń: biblioclepto, biblioladrón, bibliopirata. Przytacza też niezwykle ciekawy sonet autorstwa Serafína Estébaneza Calderóna adresowany do Bartolomé José Gallarda ${ }^{13}$, w którym używa najbardziej wyszukanych eufemizmów określających złodzieja książek, jak np. garrapata (kleszcz), caco (włamywacz), carcoma (kornik). Kończy się on konkluzją, że Gallarrdo, któremu archiwum w Simancas mieści się w kieszeni, wypije jak zupę pełną książek Afrykę i Europę ${ }^{14}$. W języku polskim pojawiają się określenia księgołap zasłużony, smykała pożyteczny ${ }^{15}$.

\section{OTWARTA TWIERDZA: NAKAZY, PRZEKLEŃSTWA I ŁAŃCUCHY}

Książki, czy to w formie zwojów czy kodeksów, już od samego początku swoich dziejów stanowiły obiekt pożądania. Dla jednych miały wartość materialną, dla innych sentymentalną. Były czymś więcej niż tylko przedmiotami, przecho-

10 Basbanes 1995.

${ }^{11}$ Holbrook 2001.

12 Szyndler 1982, s. 164.

${ }_{13}$ B.J. Gallardo (1776-1852) - wielki erudyta, bibliotekarz i pisarz hiszpański, autor „Ensayo de una biblioteca española de libros raros y curiosos”, biblioman, złodziej książek. Zob. Gallego 2006, s. 227-237.

${ }^{14}$ Albero Suárez 2017, s. 30-31.

15 Szyndler 1982, s. 175-180. 
wywały idee, myśli i marzenia pokoleń, które odeszły już w niebyt. Kolekcjonerzy książek skupiali wokół siebie rzesze intelektualistów, którzy łaknęli właśnie dyskusji o ideach. O ich sile pisał Anders Rydell:

W książkach była olbrzymia siła. Mogły działać jak broń, brzmiąca długo po tym jak ucichło dudnienie artylerii. Są bronią nie tylko jako propaganda, ale także jako forma wspomnień. Ktokolwiek posiada słowo, ma siłę nie tylko by je interpretować, ale też by pisać historię ${ }^{16}$.

Kto miał dostęp do książek, panował nad przeszłością i rościł sobie prawo do pisania historii. Nie zawsze jednak losy książek należały do wielkich tego świata, a dużą rolę jako czynnik sprawczy w historii odgrywał przypadek. Zazwyczaj myśląc o zmienności losów książek używa się wyrwanych z kontekstu słów Terentianusa Maurusa habent sua fata libelli ${ }^{17}$ - „i książki mają swoje losy”18. W istocie jednak, to „od pojętności czytelników zależy los książek” - pro captu lectoris habent sua fata libelli ${ }^{19}$. Na gruncie polskim przypominał o tym filolog klasyczny Józef Budzyński ${ }^{20}$, a heksametr Terentianusa Maurusa analizował Marek Piechota.

Troska o los książek była bolączką wszystkich, którzy poświęcali im nierzadko całe życie, czasami ryzykując bardzo wiele. I nie mam na myśli wyłącznie przypadku bibliofila Henryka Boularda, który tak umiłował książki i ich kolekcjonowanie, że zginął pod stosem książek, bo sięgnął nieostrożnie po jeden z okazów swojej kolek$\mathrm{cji}^{21}$. Z dbałości o właściwe obcowanie z książkami powstały formuły: Qui servare libris preciosis nescit honorem, Illius a manibus sit procul iste liber ${ }^{22}$ („niech ta książka nigdy nie trafi w ręce człowieka, który nie wie jak ją właściwie traktować”, tłum. M.K.) lub Dulcis amice, gravem scribendi attende laborem: tolle, aperi, recita, ne laedas, claude, repone ${ }^{23}$ („Drogi przyjacielu, zważ na wielki wysiłek skryby. Weź mnie, otwórz, przeczytaj, nie krzywdź mnie, zamknij i odłóż z powrotem”, tłum. M.K.).

Jednym z przykładów dbałości o książkę jest traktat Ryszarda de Bury’ego napisany w 1345 roku, a znany polskim czytelnikom jako „O miłości do ksiąg to jest Philobiblon traktat łaciński Ryszarda de Bury” w tłumaczeniu Jana Kasprowicza (1921). Ryszard de Bury był biskupem Durham w latach 1333-1345, nauczycielem

16 Rydell 2017, s. XIII.

17 Terentianus Maurus b.r.w.

${ }^{18}$ Losom książek poświęcony jest 14. tom Poznańskich Studiów Slawistycznych (2018), który otwiera artykuł Marioli Walczak-Mikołajczakowej i Mai Ivanowej pod tytułem „Habent sua fata libelli".

${ }^{19}$ Na pełną wersję heksametru zwracali uwagę polscy autorzy: Knieling 2016; Markiewicz, Romanowski 1990.

${ }^{20}$ Piechota 2012, s. 75.

${ }^{21}$ Szyndler 1982, s. 174.

22 Abbaye 1983, s. 18.

${ }^{23}$ Drogin 1983, s. 22. 
króla Edwarda III, wielkim bibliofilem. Swoje dzieło ukończył na krótko przed śmiercią ${ }^{24}$. We wstępie tłumaczy, że zajmuje się głównie miłością do ksiąg i z tego powodu, wzorem starożytnych, nazwał swój traktat „Philobiblon” ${ }^{25}$. W rozdziale dziewiętnastym dzieła wyraża życzenie przekazania swojego księgozbioru słuchaczom Oksfordu, wraz ze szczegółowymi zaleceniami dotyczącymi wypożyczania książek $^{26}$. Księgami miało się opiekować pięciu studentów i trzech bibliotekarzy, którzy mieli prawo wypożyczać czytelnikom książki do domu wyłącznie, jeśli biblioteka posiadała dwa egzemplarze. Warunkiem koniecznym było też uiszczenie przez czytelnika kaucji określonej przez strażników, która miała przewyższać wartość wypożyczanej książki ${ }^{27}$. Opiekunowie książek i czytelnicy mieli składać przysięgę, że będą korzystać z nich wyłącznie w celach naukowych i że nie będą wynosić ani pozwalać na wynoszenie książek poza mury Oksfordu ${ }^{28}$. Pojedynczych egzemplarzy nie można było wypożyczać, a opiekunowie książek byli zobowiązani do przeprowadzania kontroli księgozbioru. Ryszard de Bury wspomina także, co miałoby się stać:

jeśli przypadkiem księga zginie, czy to wskutek śmierci, kradzieży, oszustwa czy niedbalstwa, wówczas ten, któremu zginęła, jego opiekun lub też wykonawca ostatniej jego woli płaci cenę księgi i otrzymuję w zamian swoją porękę̨.

Biskup Durham wyraźnie wyprzedzał epokę, w której żył, a proponowane przez niego metody ochrony książek są aktualne i dzisiaj, choć niektórych, jak przekleństw i ekskomunik, już się (prawie) nie praktykuje.

W momencie, w którym kradzieże zbiorów bibliotecznych były coraz częstsze, interweniował papież Pius V, a kopie jego dekretu z 1568 roku umieszczano pośród zbiorów książek. Najsłynniejsza ekskomunika znajduje się w Bibliotece Historycznej Uniwersytetu w Salamance, jest powielana na pocztówkach i stała się jednym z symboli miasta. Jej słowa:

Hai excomunion

reservada a su santidad

contra qualesquiera personas,

que quitaren, distraxeren, o de otro qualquier modo

enagenaren algun libro,

24 Philobiblon.

25 Kasprowicz 1921, s. 5.

26 Życzenie Ryszarda de Bury nie zostało spełnione, ponieważ biskup był mocno zadłużony i po jego śmierci wierzyciele przejęli księgozbiór, który niestety uległ rozproszeniu.

27 Philobiblon.

28 Ibidem.

29 Ibidem. 
pergamino, o papel

de esta bibliotheca,

sin que puedan ser absueltas

hasta que esta esté perfectamente reintegrada.

Klątwa

rzucona przez papieża

przeciwko którejkolwiek z osób,

które ukradną, rozerwą, czy w jakikolwiek inny sposób

sprzedadzą jakąkolwiek książkę,

pergamin lub papier

$\mathrm{z}$ tej biblioteki,

nie będą mogli zostać uniewinnieni,

do momentu, w którym ta [książka] nie zostanie zwrócona w idealnym stanie.

Niezwykle podobna do ekskomuniki z Salamanki jest karta, którą znalazłam w księgarni Taifa w Barcelonie, dotycząca złego traktowania książek:

Kto szkodzi książce,

drze ją, tnie, niszczy, kradnie czy ukrywa

wyspowiada się nieczysty, bluźnierczo na umyśle i stręczycielsko

że chce oszczędzić innym tego, co jego chora dusza

nie pozwala mu zrozumiećc ${ }^{30}$.

Pierwsze przekleństwa na złodziei książek pojawiły się tam, gdzie zaczęła się historia pisma. Sargon I, władca Akadu (?-2279 p.n.e.), najprawdopodobniej na drzwiach „biblioteki” świątynnej umieścił inskrypcję, która groziła potencjalnym złodziejom rozerwaniem wnętrzności i zniszczeniem cielesności przez potężnych bogów: Baala i Szamasza ${ }^{31}$. Niestety nie mamy pewności, czy przekleństwo dotyczyło kradnących książki, czy po prostu chcących wtargnąć do świątyni.

Najstarsze znane przekleństwo znajduje się na glinianej tabliczce z Niniwy, datowanej na panowanie króla Assyrii Aszurbanipala (668-626 p.n.e.) ${ }^{32}$. Złodziejowi tabliczki, ale także temu, kto napisze na niej swoje imię, groziło zniszczenie cielesności na ziemi i imienia z rąk bogów Aszura i bogini Belit. Zagłada imienia oznaczała zapomnienie.

30 Tłum. M.K.

${ }^{31}$ Door socket B8751 [online].

${ }^{32}$ British Museum, K 155. 
W świecie zachodnim najpełniejsze przekleństwa na niszczących rękopisy przetrwały na papirusie datowanym na panowanie Augusta, zawierającym fragmenty trzeciej i czwartej księgi „Iliady” Homera ${ }^{33}$. Słowa:

Jestem coronis ${ }^{34}$, strażnik liter, zapisano mnie trzcinką, prawą ręką i kolanem. Jeśli pożyczysz mnie komuś, weź inny [rękopis - M.K.] w zamian. Jeśli mnie wymażesz, oczernię cię przed Eurypidesem. Trzymaj się z daleka.

Anatemy, klątwy, bo tak je nazywano, ewoluowały od form najprostszych do bardziej skomplikowanych. Początkowo odnosiły się do Pisma Świętego i zakazywały jakichkolwiek zmian $\mathrm{w}$ tekście ${ }^{35}$, aby później przeistoczyć się w niemal integralną część formuł własnościowych. Z IX wieku pochodzą słowa:

Bald jest właścicielem tej książki, którą zlecił Cildowi do napisania
usilnie proszę wszystkich ludzi, w imię Chrystusa,
by żadna zdradziecka osoba nie zabrała tej książki ode mnie,
ani siłą, ani grabieżą, ani fałszywą mową.
dlaczego? Ponieważ najlepszy skarb nie jest mi tak drogi,
jak drogie są moje książki, z którymi przychodzi łaska Chrystusa ${ }^{36}$.

W rękopisach pojawiały się formuly: anathema, Anathema sit, sit maledictus, sit maledictus per Christum i inne. Ich złożoność i obrazowość zależały od inwencji autorów. Podobnie jak wschodnie przekleństwa, odwoływały się do boskiej sprawiedliwości, która miała ukarać złodzieja.

Nie zobaczy Chrystusa,

kto weźmie tę książkę.

ten, który ukradnie

zostanie zabity klątwą ${ }^{37}$

Złodziei książek i tych, którzy je niszczyli, straszono wiecznym potępieniem, piekłem czy wykluczeniem z Kościoła. Zdarzały się też bardzo plastyczne i okrutne opisy konsekwencji kradzieży:

Jeśli ktokolwiek weźmie tę książkę, niech umrze śmiercią, niech będzie smażony na patelni, niech pojmą go choroba i gorączka, niech będzie łamany na kole i powieszony. Amen ${ }^{38}$

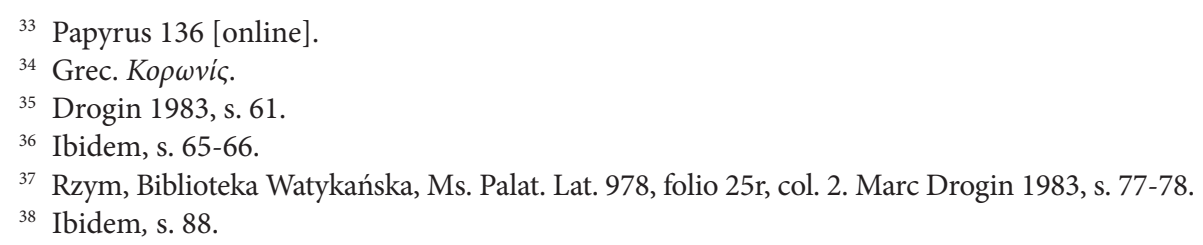


Podobną wymowę ma anatema z klasztoru San Pedro w Barcelonie:

Temu, kto ukradnie albo pożyczy i nie zwróci książki swojemu właścicielowi niech jego ręka zmieni się w węża i go rozerwie, niech dopadnie go paraliż, a wszystkie członki [jego ciała] się wykrzywią. Niech zmarnieje z bólu prosząc na całe gardło o miłosierdzie i niechaj nie ustaje jego agonia, aż do czasu, kiedy będzie piszczeć w rozkładzie. Niech szczury z biblioteki odgryzają jego wnętrzności jako sprawdzian wiecznego robaka. I kiedy wreszcie dotrze do swojego końca kary, niech płomienie z piekła zjedzą go na zawsze ${ }^{39}$.

W Polsce także umieszczano przekleństwa na złodziei książek: „Kto mi te kżaskij [!] ukradnie temu po sami łokiecz ręka upadnie” z dopiskiem z XVII wieku: „Kto te ksiaski pisał bodai na szubiniczij wisiał abi iż drugie ras nie pisał” ${ }^{40}$. Oraz „Kto ti ksziąszki ukradnie temu reka upadnie akto ie przekriie temu reka ugnie deo gratias" ${ }^{41}$. Lub też:

Kto książki złośliwie mi kradnia lub psuie, niech dyabeł go porwie y srodze katuie.

kto w książkach smaruie lub skazy w nich czyni, ten ryj miast gęby niech ma na kształt świni.

kto karty zagina czy latem, czy wiosną, niech uszy mu długie jak osłu wyrosną. kto książki mi łamie i karty wydziera, ten śmiercią najsroższą niech prędko umiera.

to jest moia książka,

a kto jey krzywdę uczyni, niechaj mu się stanie, jako wyżei powiedziano jest ${ }^{42}$.

Poza anatemami istniał inny sposób ochrony książek. Najcenniejsze zbiory umieszczano w skrzyniach, które zamykano na klucz bądź też przywiązywano je łańcuchami, aby żaden czytelnik nie był w stanie przywłaszczyć sobie cennego dzieła. Określa się je mianem libros encadenados lub chained books. W latach 1484-1786 książki przywiązane łańcuchami do biurek znajdowały się w Colegio Mayor de Santa Cruz w Valladolid (w Hiszpanii) ${ }^{43}$. Do dziś można je zobaczyć w zaledwie kilku bibliotekach ${ }^{44}$, między innymi w Zutphen (Holandia).

\footnotetext{
39 Ibidem.

40 Sd. 608.2959.

41 Sd. 602.1553.adl.

42 Poznański 1958, s. 245.

43 Galindo Azkunaga 2014, s. 26.

44 Patowary 2015.
} 


\section{ETYCZNY ASPEKT KRADZIEŻY KSIĄŻEK}

Ocena moralna kradzieży książek jest od dawien dawna kwestią dyskusyjną, choć wydawać by się mogło, że nie powinno tak być. Często analizuje się ją z przymrużeniem oka, usprawiedliwiając kradzieże faktem, że nawet najwięksi, jak np. Petrarka, pożyczali książki, by je oddać na greckie Kalendy. Relatywizacji sprzyja także używanie słownictwa zdejmującego przynajmniej część odium ze złodzieja książek, np. „książkołap zasłużony” czy „smykała pożyteczny”" Miguel Albero Suárez twierdzi, że kradzież książek to un delito, con buena prensa czyli „przestępstwo z dobrą prasą"46. Urszula Pałysińska, wyróżniając powody kradzieży w bibliotekach, zauważyła, że ich większą liczbę notuje się w czasie sesji egzaminacyjnych. Jej zdaniem na kradzieże mają wpływ: wysokie ceny książek, brak możliwości nabycia książki drogą legalną, niechęć do pracy z książką w bibliotece, zapał kolekcjonerski, chęć zysku oraz zabieranie książek przez roztargnienie ${ }^{47}$. Jeden ze złodziei książek Poggio Bracciolini tłumaczy kradzież tym, że książki „nie były strzeżone tak jak na to zasługiwały, znajdowały się na poddaszu niezwykle ponurym i ciemnym, w którym z trudnością mogliby zostać umieszczeni przestępcy”48. Motywy złodziei książek nie powinny nam jednak przysłaniać oceny moralnej, która winna być jednoznacznie negatywna.

W erze komputerów i książek elektronicznych narodził się inny typ kradzieży, tzw. piractwo. Polscy naukowcy pod kierunkiem prof. Michała Krawczyka z Wydziału Nauk Ekonomicznych Uniwersytetu Warszawskiego dowodzili, że nie ma ono realnego wpływu na sprzedaż książek. Ich badania jednak, dające w pewnym sensie przyzwolenie na kradzież, nie powinny być brane pod uwagę ze względu na wadliwą metodologię pracy ${ }^{49}$.

Wraz z upływem czasu konsekwencje kradzieży książek zmieniały się od kary śmierci do kary finansowej. W średniowieczu, gdy manuskrypty miały olbrzymią wartość, jak pisze Marc Drogin, niektórzy za skradzione książki oddawali życie. W XII wieku, niedaleko Monasterium St. Alban, żył złodziej książek.

\footnotetext{
${ }^{45}$ Szyndler 1982, s. 175.

46 Albero Suárez 2017, s. 37.

${ }^{47}$ Pałysińska 2018.

${ }^{48}$ Addington Symonds 1907, s. 99.

49 Wskazał ten problem Oskar Grzelak autor bloga „Niestatystyczny” (Grzelak 2017). Wyniki badań są oparte na mało reprezentatywnej próbie, gdyż z kilkudziesięciu wydawnictw w badaniu zgodziło się wziąć udział jedynie 10, wybrano 120 par książek, z których jeden tytuł poddawano ochronie antypirackiej, a drugi żył swobodnie w sieci. Wykazano, że działania antypirackie nie miały wpływu na sprzedaż książek, która była bardzo podobna dla książek objętych i nieobjętych ochroną. Może to prowadzić do niebezpiecznego wniosku, że z piractwem w sieci nie trzeba walczyć i dawać przyzwolenie na tego typu kradzież.
} 
Niestety, ukradzione przez niego książki spłonęły w pożarze domu, a on sam musiał wstąpić do klasztoru i zostać mnichem ${ }^{50}$. Nierzadko też wieszano ludzi. Bibliotekarz Elois Pichler za kradzież czterech tysięcy niezwykle cennych książek z Biblioteki w Petersburgu został w 1871 roku zesłany na Syberię ${ }^{51}$. Dzisiaj w polskim systemie prawnym kradzież książki jest traktowana jako czyn zabroniony pod groźbą kary, o którym mowa w art. $278 \$ 1$ kodeksu karnego ${ }^{52}$. Dla kwalifikacji prawnej czynu ważna jest wartość książki. Jeśli przekracza ona 500 złotych, za jej kradzież grozi kara od 3 miesięcy do 5 lat pozbawienia wolności, a przywłaszczenie (np. niezwrócenie do biblioteki), jest zagrożone karą pozbawienia wolności do lat 3 (art. $284 \$ 1$ kodeksu karnego). Ponad dekadę temu Sąd Rejonowy w Sandomierzu skazał prawomocnym wyrokiem byłego pracownika UJ na karę więzienia w zawieszeniu i grzywnę za kradzież ponad 70 starodruków i inkunabułów wartych nie mniej niż 875,6 tys. zł. Niestety część bezcennych zabytków została trwale uszkodzona. Sąd jednak wziął pod uwagę fakt, że oskarżony badacz współpracował z organami ścigania i oddał skradzione starodruki ${ }^{53}$. Sprawa ta doskonale egzemplifikuje, jak niewiele dzieli bibliofilię od kradzieży.

Niektórzy złodzieje książek niestety unikają wymiaru sprawiedliwości, a skradzione przez nich cenne dzieła nigdy nie wracają do bibliotek. Tak było ze starodrukiem „O obrotach sfer niebieskich” Mikołaja Kopernika (wydanie z 1543 roku), który w 1989 roku zniknął z Biblioteki Polskiej Akademii Nauk w Krakowie. W 2013 roku sprawa się przedawniła i prokuratura zamknęła śledztwo ${ }^{54}$. Kopernik nie powrócił do Krakowa, choć w ciągu 15 lat kilka razy pojawiały się informacje o próbach sprzedaży dzieła.

\section{MOTYWACJE ZŁODZEI KSIĄŻEK}

Max Stois w artykule z 1927 roku wyróżnia dwa motywy kradzieży książek: chciwość (Gewinnsucht) oraz prawdziwą potrzebę (wirkliche Not $)^{55}$. Pierwszy $\mathrm{z}$ nich nawiązuje do odwiecznego problemu kradzieży książek powodowanych chęcią zysku, sprzedaży dzieła lub jego części składowych (np. bogatej zdobionej oprawy). Złodziej książek jawi się nam jako zwykły przestępca, dla którego nie ma większego znaczenia, co w danym momencie kradnie. Często też może działać na zamówienie. Sprawa nie jest jednak tak prosta i niemal każdy przypadek kradzieży

\footnotetext{
50 Drogin 1983, s. 32.

51 Stuart 1988, s. 401-22.

52 Jaka sankcja 2018.

53 Więzienie w zawieszeniu dla profesora UJ 2007.

54 Drożdżak 2014.

55 Stois 1927, s.174.
} 
należałoby rozpatrywać indywidualnie. Chilijski dziennik „El Mercurio” wyróżnia trzy typy złodziei książek:

Pierwszy z nich to złodziej okazjonalny (un ladrón ocasional), który kradnie kiedy ma okazję to zrobić. Widzi książkę, która przyciąga jego uwagę i jeśli może ją ukraść, to bez żadnego problemu ją zabiera. I nawet nie dokonuje zakupu, aby ukrywać (to). Druga kategoria to złodziej oświecony (un ladrón ilustrado), który chce przeczytać książkę, ale nie ma pieniędzy; jego desperacja jest taka, że ostatecznie ją kradnie. W ostatniej kategorii, najbardziej nikczemnej według księgarzy, są złodzieje na zamówienie (un ladrón por encargo) ${ }^{56}$.

Drugim motywem, zdaniem Stoisa, jest prawdziwa potrzeba kradzieży książek, której nie można ująć w jakiekolwiek ramy interpretacyjne. Wzorem pochodzącego z Florencji wybitnego humanisty Poggia Braccioliniego (1380-1459), który przeczesywał europejskie biblioteki klasztorne, znajdując takie okazy, jak np. „Kształcenie mówcy” (Institutionis oratoriae libri XII) Kwintyliana, szli Polacy. Bartłomiej Szyndler pisze o księgołapach pożytecznych, że „wyrządzali szkody $\mathrm{w}$ małych prowincjonalnych bibliotekach i zaniedbanych księgozbiorach, pragnąc uchronić najcenniejsze księgi przed zniszczeniem i zachować je w dla kultury narodowej” ${ }^{57}$. Pośród nich był założyciel Zakładu Narodowego im. Ossolińskich we Lwowie - Józef Maksymilian Ossoliński (1748-1826) ${ }^{58}$. Innym wielkim złodziejem książek był autor „Słownika języka polskiego”, bibliotekarz Samuel Bogumił Linde (1771-1847), który podróżował od klasztoru do klasztoru i zabierał co ważniejsze dzieła. W liście z 25 sierpnia 1799 roku pisał:

Przedonegdaj wycieczkę zrobiłem na Kalwaryą, gdzie u d.... dumnych bernardynów (...) widział Biblię Radziwiłłowskq caluteńką; Kraińskiego postyllę; czeskie opisanie świata bardzo ciekawe; Miaskowskiego rytmy (...), ale też tylko widziałem, bo tam ni perswazje, ni pieniądze, ani zamiany, ani rewersy, ani pogróżki nic nie pomogą, chyba ich za łeb wziąć trzeba, a mnichy tłuste i spaśne, a ja chudy (...) Nie pozwolili d....ki nawet spisać rejestr odłożonych. Cudem przecież udało mi się smykać: Łukasza Górnickiego rozmowę złodzieja z czartem in quarto, pisemko bardzo ciekawe i jeszcze trzy insze kawałki i wierszem, i prozą pisane, których jeszcze nie mając na dorędziu, bom je u Iżyckiego zakopał dla bezpieczeństwa, nie opiszę, za to zaś położę tu Panu rejestr najciekawszych łupów krakowskich i chebdowskich, jak nic co w rękę wpadnie, bo skąd i jak co przyszło, czy per fas czy nefas, sam już nie pamiętam, a będzie tego ze dwie paki nieszpetne ${ }^{59}$

Innym smykałą był Tadeusz Czacki, któremu niestraszne były papieskie ekskomuniki, i po którego wizytach odnotowywano w katalogach klasztornych: „Tę

\footnotetext{
56 Quiñonero 2007.

57 Szyndler 1982, s. 175.

58 Zob. Lepkowska 2018.

59 Szyndler 1982, s. 176-177.
} 
książkę skradł Czacki”60. Często w bibliografiach znanych osób, które zajmowały się smykaniem książek, znajdują się fragmenty mówiące o trudnych do wyjaśnienia okolicznościach, w jakich dane książki znalazły się w ich księgozbiorach ${ }^{61}$. Ocena moralna tych działań jest niemożliwa, ponieważ intencje kradnących książki nierzadko były szlachetne. Tadeusz Mikulski twierdzi, że: „Zbierać książki znaczyło wówczas ocalać fragmenty przeszłości narażonej na zatracenie"62.

W 1816 roku szwajcarski doktor André Matthey stworzył i zdefiniował pojęcie kleptomanii jako pragnienia kradzieży i jednocześnie kradzież bez powodu. Co ciekawe, w XIX wieku we Francji postrzegano kleptomanię jako „chorobę kobiet"63. Istotnym elementem bibliokleptomanii jest drugi człon terminu, mania, czyli obłęd, szaleństwo powodowane żądzą kradzieży książek lub/i ich posiadania. Prowadzi to do wniosku, że bibliokleptomania jest chorobą, choć jak wskazuje Jerzy Pobocha, wyśmiewano się z niej i traktowano jako hobby ${ }^{64}$. Z tego powodu zatytułował Albero Suárez swój esej z 2009 roku „Enfermos del libro. Breviario personal de bibliopatías propias y ajenas” (czyli „Chorzy na książkę, dziennik osobisty bibliopatów własnych i obcych” ${ }^{65}$. Jest to przegląd historii bibliokleptomanów, pośród których pojawia się m.in. Bartolomé José Gallardo (1776-1852). Wszystkich jednak łączy jedno, maladie, czyli choroba.

Christopher Brown-Syed wskazuje, że problem bibliokleptomanii otwiera droge do możliwości współpracy pomiędzy bibliotekarzami, archiwistami, psychologami i osobami zajmującymi się naukami behawioralnymi ${ }^{66}$. Czy do tej grupy jednak można zaliczyć Stephena Blumberga, który ukradł 20 tysięcy książek i 10 tysięcy rękopisów tylko po to, by pobić rekord Guinnessa? Co nim kierowało? Ambicja, chciwość czy choroba? Z kolei księżna Izabela Czartoryska nie zwracała książek do bibliotek, aby w trudnych czasach rozbiorów budować swoją bibliotekę na Puławach ${ }^{67}$.

Niektórzy badacze uznają, że bibliokleptomania to miłość do książek, która wymknęła się spod kontroli. Hobby przekształca się w zaburzenie psychiczne. Jak pisał Max Sander: „przyjazny i ciepły ogień hobby zamieniał się w niszczycielski i gwałtowny pożar, w burzę uwolnionych i żarliwych namiętności”68. Czy jednak powinniśmy wszystkie przypadki kradzieży książek klasyfikować jako przykłady bibliokleptomanii? Używanie, a raczej nadużywanie terminu „bibliokleptomania”

\footnotetext{
60 Ibidem, s. 177.

61 Zob. Walczak-Niewiadomska 2007, s. 97.

62 Za Błażejewicz 1975, s. 94.

63 Albero Suárez 2017, s. 191.

64 Zob. Pobocha 2012, s. 114.

65 Albero Suárez 2009.

66 Brown-Syed 1999, s. 83-89.

67 Szyndler 1982, s. 179.

68 Basbanes 1995, s. 33.
} 
jest w moim odczuciu niebezpieczne, ponieważ zdejmuje ciężar moralny ze sprawcy, którym kierują często bardzo różne motywy. Ucieczka w chorobę bywa sposobem na uniknięcie odpowiedzialności za swoje czyny.

Anatol France słusznie ostrzegał przed pożyczaniem książek, ponieważ jedyne, co miał w swojej bibliotece, to książki pożyczone mu przez przyjaciól ${ }^{69}$. Kwestia niezwracania książek do bibliotek jest dla Albero Suáreza sprawą na peryferiach bibliokleptomanii. Odróżnia on zdecydowanie celową kradzież (robo) od niezwrócenia książki (el préstamo sin devolución). Kluczem do zrozumienia różnicy jest intencja sprawcy ${ }^{70}$. Czytelnik, który zapomina zwrócić książkę (lub nawet ją gubi), nie działa właśnie intencjonalnie. Jego motywy niezwrócenia książki do biblioteki (czy pożyczonej od przyjaciół) mogą być różne, choć warto zaznaczyć, że jest to jednak wyraz braku dbałości o książkę.

Albert Cim pisał, że „w każdej epoce i w każdym miejscu wypożyczający byli gorsi od szczurów czy myszy, gorsi od wody czy pożaru, horror dla bibliofilów"71. W gronie czytelników, którzy nigdy nie oddawali książek, znajdują się uczeni jak Abel François Villemain.

Innym typem książkowego złoczyńcy jest barbarzyńca. Barbarzyńcą nazywam każdego, kto niszczy książki, zarówno ich fizyczną postać, jak i świat idei, który stał za ich powstaniem. Mam na myśli imaginarium autora, które ulega unicestwieniu czy też skrzywieniu przez czytelnika-barbarzyńcę. Jest on złodziejem myśli, idei, historii i pamięci; kimś, kto profanuje przeszłość. W książkach bowiem jest opisane ludzkie życie, które powinno być zapamiętane na zawsze - in libro vitae scribantur et in memoria eterna habeantur ${ }^{72}$. Pośród barbarzyńców znajdą się czytelnicy, którzy - jak pisał Ryszard de Bury:

zaledwie bowiem nauczyli się odcyfrować litery, a już bawią się w nieszczęśliwych komentatorów tych tomów przecudnych, które im powierzono; a gdzie dawniej szeroki był margines naokoło tekstu, widać obecnie potworny alfabet, albo jakąś inną bezwstydność, tak, jak przedstawia się w ich wyobraźni i jak ją w czelności swej maluje cyniczne pióro. Tam jakiś łacinnik, tam sofista, tam inny niedowarzony jakiś pisarek próbuje zręczności swego pióra i w ten sposób widzimy bardzo często, że najpiękniejsze księgi tracą wartość i pożytecznośćc ${ }^{73}$. Istnieje także pewien gatunek złodziei, w wysokim stopniu kaleczących księgi, ponieważ, dla napisania listu, obcinają brzegi stronic i odgryzają nawet kartki ochronne. Świętokradztwo takie powinno być pod grozą klątwy zakazane ${ }^{74}$.

\footnotetext{
69 Albero Suárez 2017, s. 57.

70 Ibidem, s. 57-61.

71 Cim 1903.

72 Drogin 1983, s. 82.

73 Myśl ta jest argumentem za istnienien książki w sferze sacrum.

74 Philobiblon.
} 
Barbarzyńcami są ci, którzy bezrefleksyjnie niszczą książki, piszą po nich, rysują czy wyrywają strony. $Z$ drugiej strony jednak noty marginalne mogą być dowodem na to, że lektura budziła refleksję, krytykę i przede wszystkim olbrzymie emocje ${ }^{75}$.

Najgorszym złodziejem książek jest jednak ten, kto z premedytacją kradnie ludzkości dzieła, skazując je na zagładę, niepamięć. Heinrich Heine pisał nie bez racji, że „tam gdzie pali się książki, tam będzie paliło się ludzi”76. Już od zarania dziejów mogliśmy obserwować tego typu działania, nieodmiennie związane z wojnami. Wielokrotnie wspominany już Ryszard de Bury w siódmym rozdziale traktatu „Philobyblon” zatytułowanym „Skarga ksiąg na wojny”, pisze:

\begin{abstract}
Wszechmocny Twórco i Miłośniku pokoju, wypleń narody, które pragną wojny, więcej szkód przynoszącej księgom, niż wszystkie inne plagi ziemi (...)

Zaiste niema ${ }^{77}$ godnego bolu dla dostatecznego opłakiwania ksiąg wszystkich, które dzięki okolicznościom wojny zmarniały na całym świecie. Przypominamy tylko łez pełną skargę Aulusa Geljusza na straszliwie zniszczenie, jakie w pierwszej wojnie aleksandryjskiej sprawiły wojska posiłkowe, które siedemkroć sto tysięcy ksiąg przez Ptolemeusza przywiezionych do Egiptu, stało się pastwą płomieni. Jakiż to szczep atlantycki zginął wówczas! Ruch gwiazd, konjunktury planet, istota drogi mlecznej, prorocze komety, jednem słowem wszystko, co istnieje na niebie, czy w powietrzu! Kto nie drżał przed temi niegodziwymi całopalnemi ofiary, gdy inkaust poświęcono krwi, gdy błyszczący śnieg szeleszczących pergaminów pokrywał się krwią, gdy płomienie trawiące niszczyły tyle niewinnych, z ust których kłamstwo nigdy nie wyszło, gdy ogień, nie szczędzący niczego, zamieniał w popiół one tysiące pism, wieczystą głoszących prawdę $e^{78}$.
\end{abstract}

Za pierwszy rabunek polskich dóbr kultury na olbrzymią skalę uznaje się potop szwedzki, podczas którego skradziono dzieła gromadzone od czasów średniowiecza. Jak pisał Otto Walde, „w złocie i srebrze, (...) w bibliotekach i archiwach (...)"79. Przykłady można mnożyć.

W maju 1933 roku, berlińscy studenci ceremonialnie spalili dzieła m.in. Thomasa Manna, Kurta Tucholsky'ego i Stefana Zweiga ${ }^{80}$. Akt ten, jak twierdzi Anders Rydell, przyczynił się do ugruntowania przeświadczenia, że naziści byli kulturowymi barbarzyńcami ${ }^{81}$, co nie było do końca zgodne z prawdą. Świadczy o tym chociażby olbrzymia kolekcja książek Heinricha Himmlera, do której wcielono między innymi książki żydowskie pochodzące z Wielkiej Synagogi w Warszawie. Nie bez znaczenia jest fakt, że kradziono w pierwszej kolejności książki należące

\footnotetext{
75 Bieńkowska 1976, s. 82.

76 Heine 1821.

77 Pisownia oryginalna tłumaczenia Kasprowicza.

78 Bury Richardus de, Philobiblon 2017.

79 Kosmanowi 1981, s. 211-212.

80 Rydell 2017, s. 10.

81 Ibidem, s. 11.
} 
do Żydów. Chciano ich całkowitego unicestwienia - jakby „ich życia, wspomnienia i myśli nigdy nawet nie istniały" ${ }^{\prime 2}$. W Polsce działało w tych czasach Sonderkommando dowodzone przez archeologa Petera Paulsena, zajmujące się grabieżą bibliotek:

Skala grabieży w Polsce była olbrzymia z kradzieżą około 2 do 3 milionów książek. Najbardziej wartościowe z nich, włączając więcej niż dwa tysiące inkunabułów ${ }^{83}$, były wysyłane do Niemiec ${ }^{84}$.

Jak szacują badacze, zniszczonych zostało około 15 milionów polskich książek, a Sonderkommando, które nie zdążyło ukraść Biblii z Pelplina, w odwecie spaliło część biblioteki. Powstanie Warszawskie, poza życiem ludzkim, kosztowało 90\% spalonych zbiorów Biblioteki Załuskich ${ }^{85}$. Niestety podobnych przykładów jest wiele, nie tylko w Polsce. Należy jednak dodać, że w każdym momencie historycznym istnieli obrońcy książek, jak np. tzw. Brygada Papieru w Wilnie lub Talmudkommando w Theresienstadt.

Fernando Báez w książce „Historia universal de la destrucción de libros” $\$ 6$ przywołuje postać profesora historii średniowiecznej w Bagdadzie, który po bombardowaniu miasta 20 marca 2003 roku powiedział „nasza pamięć już nie istnieje. Kolebka cywilizacji, pisarstwa i praw została spalona. Zostały tylko zgliszcza" ${ }^{87}$. Podobny lament nad utraconym dziedzictwem trwa nieustannie. Na tego typu barbarzyńskie działania Hiszpanie używają określenia memoricidio - „pamięciobójstwo": niszczenie/zabójstwo pamięci, kultury. Choć fikcyjne, adekwatne są słowa z filmu „Kleopatra” (1963 r.) z Elizabeth Taylor, będące reakcją królowej na podpalenie Biblioteki Aleksandryjskiej w 48 r. p.n.e.:

Jak śmiesz, ty i reszta twoich barbarzyńców podkładać ogień pod moją bibliotekę? Graj zdobywcę, cokolwiek chcesz, potężny Cezarze! Gwałć, zabijaj, plądruj tysiące, miliony istnień ludzkich! Ale ani ty, ani żaden inny barbarzyńca nie ma prawa niszczyć ani jednej ludzkiej myśli ${ }^{88}$.

W kulturze popularnej na trwałe zapisała się postać Liesel Meminger, bohaterki powieści Markusa Zusaka ${ }^{89}$, małej Niemki, która w czasie II wojny świato-

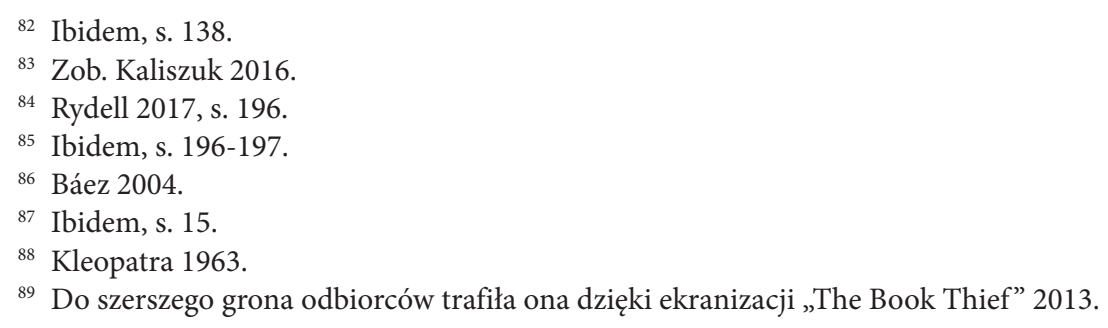


wej trafia do rodziny zastępczej i znajduje pocieszenie w kradzionych z biblioteki burmistrza książkach. Jej los trafia do serc czytelników i utrwala, chcąc nie chcąc, pozytywny obraz kradzieży książek.

Biorąc pod uwagę motywy, które kierowały złodziejami książek, chciałabym wyróżnić ich następujące kategorie:

- pospolici złodzieje kierujący się żądzą zysku;

- obsesyjni posiadacze owładnięci manią;

- księgołapi pożyteczni, których nadrzędnym celem jest ratowanie książek;

- barbarzyńcy - kradnący i niszczący książki z obiektywnie złych pobudek,

- „niewinni” złodzieje, a więc często osoby przypadkowe, które zapominają o oddaniu książek, gubią je lub też popełniają kradzież, nie mając złych intencji (jak Liesel) ${ }^{90}$.

\section{PODSUMOWANIE}

Odpowiedź na pytanie, czy złodzieje książek są szlachetnymi szaleńcami, nie może być jednoznaczna - podobnie jak ocena moralna wszystkich tych, którzy dopuszczali się kradzieży. Złodzieje są tak różni, jak książki, które padały ich łupem. Każda z proponowanych przez badaczy typologii osób kradnących książki, w tym i moja, ma jedną zasadniczą wadę - niedostatecznie uwzględnia ich olbrzymie zróżnicowanie, osobowości złodziei, ich życie, uwarunkowania historyczne i społeczne, a wreszcie motywy.

O ile jednak kradzież w imię wyższych ideałów (jak np. dbałość o zachowanie dziedzictwa narodowego) można w pewnym stopniu usprawiedliwić, o tyle niskie pobudki sprawców zasługują na potępienie. Chciwość, żądza posiadania, obsesja na punkcie książek to ciemne strony problemu bibliomanii. Jednak za najgorszy typ złodziei książek uważam tych, którzy je niszczą, gdyż okradając ludzkość ze świata dawnych idei, tym samym okradają ją z historii.

\section{NOBLE MADMEN OR COMMON THIEVES? SELECTED ASPECTS OF BOOK THEFT ACROSS CENTURIES}

\section{Summary}

The paper focused on the phenomenon of book theft, which often tends to be erroneously called bibliokleptomania. The essential goal is to demonstrate the motivations of book thieves and, relying on that basis, develop a typology of such individuals. As a starting point, the author discusses various notions used to denote the practice, such as bibliophilia, biblioholism, and the aforementioned

${ }^{90}$ Zdaję sobie sprawę z tego, że natura ludzka jest na tyle złożona, że często motywy kradzieży (i tym samym zaproponowane kategorie) mogą się ze sobą splatać. 
bibliokleptomania. Consequently, the author suggests her own term, namely straightforward book theft, which she considers to be the most appropriate in the circumstances. Subsequently, the author outlines the measures used in the past to protect libraries against theft, especially various charms and anathemas, and then goes on to discuss the ethical aspect of book theft. The latter is the most disputable element, as the assessment of the practices tend to be relativized, while the arguments employed to justify book thieves are highly questionable. Finally, the motivations behind the act are analysed in order to formulate a typology of those who commit it (common thieves, useful book-snatchers, obsessive owners, barbarians and "innocent" thieves). Given the complexity of the phenomenon, the author finds that the title question cannot be conclusively answered, as there are both noble madmen and "real" criminals among book thieves.

\section{Bibliografia}

Abbaye Port-Valais S.-B. 1979, Colophons de manuscrits occidentaux des origines au XVI ${ }^{\mathrm{e}}$ siècle 6, s. 478.

Addington Symonds J. 1907, Renaissance in Italy: The Revival of Learning, 2, New York.

Báez F. 2004, Historia universal de la desctrucción de libros. De las tablillas sumerias a la guerra de Irak, Barcelona.

Báez F. 2009, El saqueo cultural de América Latina. De la conquista a la globalización, Barcelona.

Basbanes N.A. 1995, A Gentle Madness. Bibliophiles, Bibliomanes, and the Eternal Passion for Books, New York.

Bieńkowska B. 1976, Staropolski świat książek, Wrocław.

Błażejewicz O., Linde S.B. 1975, Bibliotekarz i bibliograf, Wrocław.

Brown-Syed Ch. 1999, Some Observations on Systematic Book Theft, Library \& Archival Security 15.1., s. 83-89.

Bury Richardus de, Philobiblon, seu de Amore Librorum, 1345 [online]. Badishe Landes Bibliothek [dostęp: 2018-10-10]. Dostępny w Internecie: <https://digital.blb-karlsruhe.de/blbihd/Inkunabeln/content/titleinfo/4088233>.

Cim A. 1903, Amateurs et voleurs de livres, Paris.

Door socket [online]. Penn Museum [dostęp: 2018-10-13]. Dostępny w Internecie: <https://www. penn.museum/collections/object/219786>.

Drogin M. 1993, Anathema! Medieval Scribes and the History of Book Curses, Totowa.

Drożdżak A. 2014, Astronomiczna kradzież. Złodziej Kopernika nieuchwytny od 15 lat! [online]. Gazeta Krakowska, 20 lutego 2014 [dostęp: 2018-10-13]. Dostępny w Internecie: <https:// gazetakrakowska.pl/astronomiczna-kradziez-zlodziej-kopernika-nieuchwytny-od-15-lat/ ar/3340297>.

Galindo Azkunaga A. 2014, El Libro 22 de la Biblioteca Histórica Santa Cruz de Valladolid: un registro minucioso de las vidas de aquellos que controlaron la España Moderna.

Gallego Lorenzo J. 2006, Apuntes biográficos y bibliográficos sobre la figura de D. Bartolomé José Gallardo (1776-1852), Estudios humanísticos. Historia 6, s. 227-237.

Grzelak O. 2017, Polscy naukowcy dowiedli, że kradzież książek nie jest czynem szkodliwym?! [online]. Niestatystyczny, 9 sierpnia 2017 [dostęp: 2018-10-13]. Dostępny w Internecie: <http:// niestatystyczny.pl/2017/08/09/polscy-naukowcy-dowiedli-ze-kradziez-ksiazek-nie-jest-czynem-szkodliwym/>. 
Heine H. 1821, Almansor. Eine Tragödie, Berlin.

Holbrook J. 2001, The Anatomy of Bibliomania, New York.

Jaka sankcja za kradzież i przywłaszczenie rzeczy [online]. INFOR [dostęp: 2018-10-13]. Dostępny w Internecie: <https://www.infor.pl/prawo/wykroczenia/charakterystyka-wykroczen/261393, Jaka-sankcja-za-kradziez-i-przywlaszczenie-rzeczy.html>.

Kaliszuk J. 2016, Codices deperditi: średniowieczne rękopisy łacińskie Biblioteki Narodowej utracone w czasie II wojny światowej. Katalog rękopisów utraconych, 1-3, Wrocław.

Kleopatra 1963 [online]. IMDB [dostęp: 2018-10-13]. Dostępny w Internecie: <https://www.imdb. com/title/tt0056937/quotes $>$.

Knieling N. 2016, Pro Captu Lectoris Habent Sua Fata Libelli. Collezionismo Librario e Diffusione Delle Idee Illuminate Alla Corte Di Pietro Leopoldo. Archivio Storico Italiano 174, 1 (647), 2016, s. 107-140.

Kosmanowa B. 1981, Książka i jej czytelnicy w dawnej Polsce, Warszawa.

Kto miłuje księgi...: antologia tekstów o książce, 1958, zebrał i oprac. M. Poznański, Warszawa.

Lepkowska E. 2018, Sylwetka Józefa Maksymiliana Ossolińskiego - bibliofila, założyciela fundacji swego imienia, bibliotekarza i polityka w świetle literatury [online]. RCLIS [dostep: 2018-1013]. Dostępny w Internecie: <http://eprints.rclis.org/19568/1/ Sylwetka\%20J\% C3\%B3zefa\%20 Maksymiliana\%20 Ossoli\%C5\%84skiego\%20fini.pdf>.

Markiewicz H., Romanowski A. 1990, Skrzydlate słowa. Warszawa.

O miłości do ksiąg to jest Philobiblon traktat łaciński Ryszarda de Bury, 1921, tłum. J. Kasprowicz, Lwów. Pałysińska U. 2018, Zabezpieczenie zbiorów bibliotecznych przed kradzieżą [online]. RCLIS [dostep: 2018-10-10]. Dostępny w Internecie: <http://www.ebib.pl/2001/24/palysinska.html>.

Papyrus 136 [online]. Digitalised Manuscripts [dostęp: 2018-10-13]. Dostępny w Internecie: <http:// www.bl.uk/manuscripts/ FullDisplay.aspx?ref=Papyrus_136>.

Patowary K. 2015, The Last Surviving Chained Libraries [online]. Amusing Planet, 2 kwietnia 2015 [dostęp: 2018-10-13]. Dostępny w Internecie: <https://www.amusingplanet.com/2015/04/ the-last-surviving-chained- libraries.html>.

Piechota M. 2000, Saplicowie - Soplicowie: na marginesie pewnej odręcznej notatki w osiemnastowiecznej „Etyce chrześcijańskiej” Wincentego Houdry’ego, [w:] M. Piechota (red.), „Pieśni ogromnych dwanaście...”: studia i szkice o „Panu Tadeuszu”, Katowice, s. 46-61.

Piechota M. 2012, Wyrwane z kontekstu. O obyczaju nadawania nowych znaczeń fragmentom cudzych myśli. Rekonesans, [w:] M. Bernacki et al (red.), Zaczytani: tom jubileuszowy dla profesor Anny Węgrzyniak, Bielsko-Biała, s. 71-106.

Pobocha J. 2012, Impulse-Control Disorders in Forensic Psychiatry, Sveikatos Mokslai/Health Sciences $22.2(81)$, s. 114-118.

Quiñonero J.P. 2007, Importancia del robo para el futuro de la lectura [online]. Una temporada en el infierno [dostęp: 2018-10-13]. Dostępny w Internecie: <http://unatemporadaenelinfierno. net/2007/01/19/importancia-del-robo-en-el-futuro-de-la-lectura/>.

Revista Internacional del Libro, Digitalización y Bibliotecas 2.2, s. 22-36.

Rohde E. 2007. Psyche. Kult duszy i wiara w nieśmiertelność u starożytnych Greków, tłum. J. Korpanty, Kęty.

Rydell A. 2017, The Book Thieves, The Nazi Looting of Europe's Libraries and the Race to Return a Literary Inheritance, tłum. Henning Koch, Washington.

Stois M. 1927, Das gestohlene Buch, Zentralblatt fur Bibliothekswesen 44, s. 174.

Stuart M. 1988, The crime of Dr. Pichler: a scholar - biblioklept in imperial Russia and his European predecessors, Libr Cult 23 (4), s. 401-22. 
Suárez Albero M. 2009, Enfermos del libro. Breviario personal de bibliopatías propias y ajenas, Sevilla.

Suárez Albero M. 2017, Roba este libro. Introducción a la bibliocleptomanía, Madrid.

Szyndler B. 1982, I książki mają swoją historię, Warszawa.

Terentianus Maurus, b.r.w., De litteris, De syllabis, De Metris, v. 1286.

Thompson L.S. 1994, Notes on Bibliokleptomania, New York.

Walczak-Mikołajczakowa M., Ivanova M. 2018, Habent sua fata libelli, Poznańskie Studia Slawistyczne, s. 11-17.

Walczak-Niewiadomska A. 2007, Ksiądz Jan Sobczyński i jego księgozbiór, Kalisz.

Wielki Słownik Języka Polskiego [online]. WSJP [dostęp: 2018-10-11]. Dostępny w Internecie: $<$ http://wsjp.pl>.

Więzienie w zawieszeniu dla profesora UJ za kradzież starodruków [online]. Gazeta Wyborcza, 2 lipca 2007 [dostęp: 2020-09-20]. Dostępny w Internecie: <http://web.archive.org/ web/20170226035718/ http://wiadomosci.gazeta.pl/wiadomosci/ 1,114873,3893310.html>.
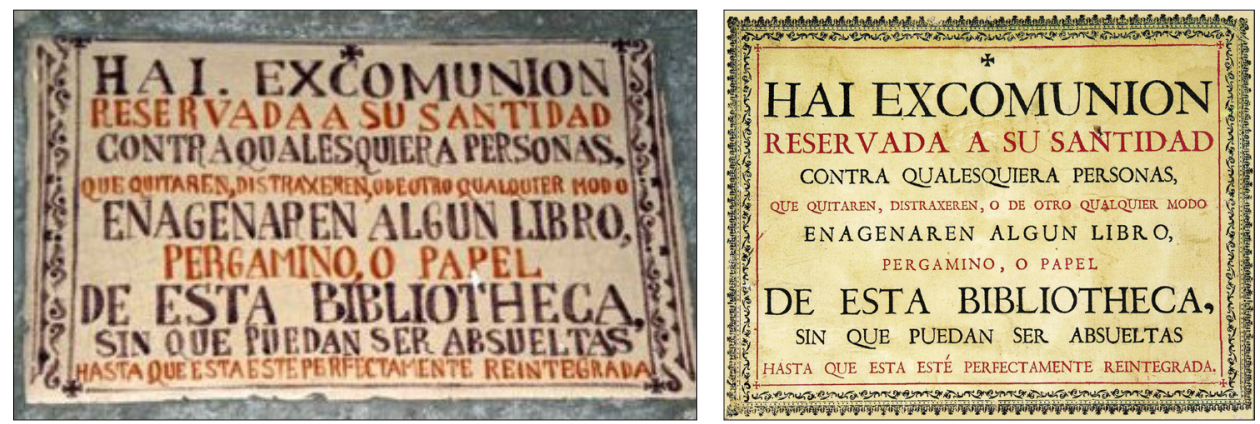

Il.1 i 2. Fotografia ekskomuniki z Salamanki i pocztówka (zbiory autorki)

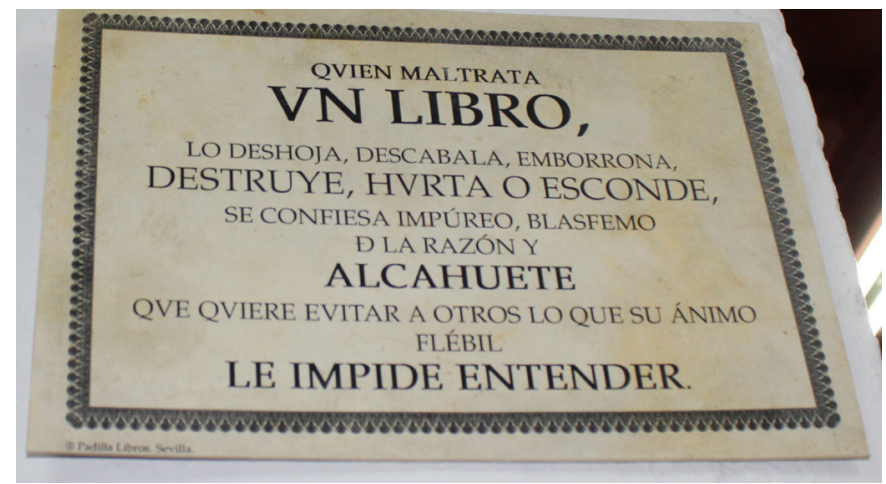

Il. 3. Fotografia karty z przekleństwem na tego, kto niszczy książki pochodząca z księgarni Taifa w Barcelonie (zbiory autorki). 


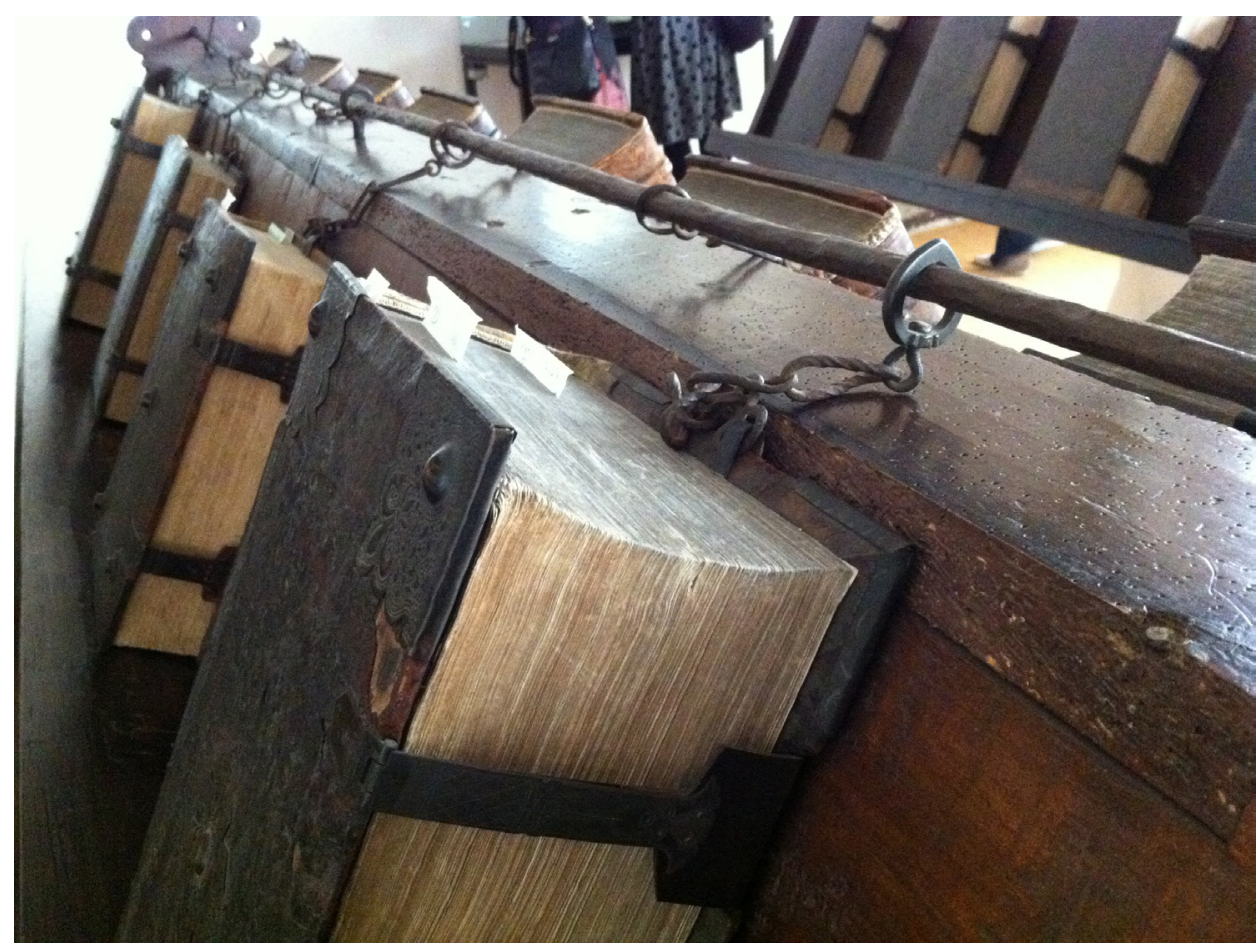

Il. 4. Fotografia biblioteki Zutphen (źródło: [online]. Medieval Fragments [dostęp: 2018-10-13]. Dostępna w Internecie: <https://medievalfragments.wordpress.com/2013/05/10/the-last-of-thegreat-chained-libraries/>. 
